\title{
Stylistics Analysis of National Geographic Magazine’s Cover June Edition
}

\author{
Vincentius Seto Ariwibowo \\ Universitas Sanata Dharma
}

\begin{abstract}
This research presented the Stylistics analysis of National Geographic magazine's cover June edition. The magazine was chosen because it is one of the magazine's newest issues by the time the researcher conducting this research. The Stylistic approach was employed to understand and reveal the magazine editor's purposes in using specific language and visual features. Considering this research analyzes visual feature; therefore, the theory of visual grammar was employed. To achieve the analysis's goal, the researcher analyzed the language features from three language levels and a feature from visual grammar. In the level of phonology, the features are assonance, alliteration, and consonance. In the level of graphology, the features are italicization, uppercase, and lowercase. In the level of typography, the features are font size and the position of the text. In the visual grammar, the feature is distance. The researcher found that the language and visual features are used in purposes. They were used to give some effects to the reader that can attract them to read the magazine. In conclusion, the stylistics was proven in revealing the editor's purposes of using language and visual feature in the magazine cover.
\end{abstract}

\section{Keywords: stylistics, visual analysis, magazine cover}

\section{Introduction}

Mass media is a tool that is used to reach mass audiences. It shares and transmits the information through either spoken text or written text. Mass media examples that transmit the spoken text are television, radio, and the popular one nowadays, podcasts. Besides, the examples of mass media that transmit the written text are newspapers, blogs, and magazines. Information and communication technologies have generated new platforms on which to read. The list includes 


\section{Jurnal DinamikA}

Volume 2 No. 2 (2021)

E-ISSN: 2723-1410

Website: https://jurnal.iainsalatiga.ac.id/index.php/dinamika/index

desktop and laptop computers, e-readers (such as Kindle and Nook), tablet computers (e.g., the iPad), and handheld devices (e.g., the iPod Touch, mobile-phones) (Baron, 2013, p. 193).

The magazine is one of the written mass media that can be in the form of digital and printed, which contains photographs, advertisements, articles, and other columns. It plays an essential role in providing information as it is described as a storehouse of information. This role is agreed by Dominick (1996), who argued that the magazine was described as 'literally storehouse of material gathered from books, pamphlets, and newspaper and bound together under one cover.' The content of the information presented in magazines represents the information and ideas of specific interests. Therefore, each magazine has its purposes and target readers. For example, National Geographic magazine represents information and ideas about nature, travel, people, etcetera. Therefore, the purpose is to inform the readers, and the target readers are people who preserve nature, like to travel, and like to observe people's culture. National Geographic is one magazine that can be found anywhere, aiming to 'illuminate and protect.' National Geographic uses several language styles that can be seen on its magazine front cover to do its aim. The language styles in National Geographic magazine's front cover are essential to attract people to read the magazine. The magazine editors and producers may use some language levels such as graphological level, phonological level, and syntactic level in terms of style. The editor of Tatler states that 'A magazine's front-cover image and coverlines are persuasive selling tools. They motivated readers - confronted with shelves of front covers competing for their attention - to buy our magazine rather than another' (McLoughlin, 2002, p. 5). It should combine persuasion and language style when it discusses magazine cover that can attract people to read. Thus, the language style on the magazine's front cover is principal for the persuasive matter. Therefore, it is worth studying.

Several studies are used as references in conducting this research. The first is an undergraduate thesis by Famila (2016) entitled "A Stylistic Analysis on The View Column in Vogue Magazine, April 2015, June 2015, and December 2015 Editions”. 


\section{Jurnal DinamikA}

Volume 2 No. 2 (2021)

E-ISSN: 2723-1410

Website: https://jurnal.iainsalatiga.ac.id/index.php/dinamika/index

This research discusses the styles in language features used in Vogue magazine's column. The second is also an undergraduate thesis by Susanto (2019) entitled "The Use of Pre-Modifiers and Post-Modifiers of Noun Phrases in Revlon Lipstick Advertisements in Female Online Magazines.” This research examines the style in syntax level, specifically pre-modifier and post-modifier as advertisment in female online magazines. The difference between this research and both these undergraduate thesis relies on the object of the study. Famila and Susanto are discussing the style inside the magazines. In contrast, this research discusses the style in the magazine's cover, specifically National Geographic magazine's cover June Edition.

The researcher chooses National Geographic magazine's cover June edition as the object of the study. It is taken from the National Geographic website at nationalgeographic.com. The magazine cover June edition is interesting to examine since National Geographic is a famous media worldwide, and it is also published in the form of digital magazines. Moreover, the style of language features and the magazine cover picture can allow the reader to understand the contents provided inside the magazine without opening it. The editor of Tatler states that 'A magazine's frontcover image and coverlines are persuasive selling tools. They motivated readers confronted with shelves of front covers competing for their attention - to buy our magazine rather than another' (McLoughlin, 2002, p. 5).

This research is expected to result in the purpose and the effect of style in language levels used in the magazine's cover. The researcher uses a stylistic approach as the leading theory in conducting this research to reach this expectation. Stylistics is the study of 'distinctive' aspects of language and representation of its purpose and effects (Verdonk, 2002, p. 4). With the stylistic approach, the purposes and effects of the magazine's covers' language levels could be revealed. For example, the noun phrase "LAST VOICES" in National Geographic magazine's cover has the purpose of informing the readers that the magazine's issue is about someone's voice or testimony. 


\section{Jurnal DinamikA}

Volume 2 No. 2 (2021)

E-ISSN: 2723-1410

Website: https://jurnal.iainsalatiga.ac.id/index.php/dinamika/index

The possible effect that can occur is that it can trigger the reader's curiosity about what voice the older woman in the picture wants to say.

\section{Research Methods}

This research examines the use of language and visual features in the magazine's cover. The magazine editors and producers may use some language levels such as graphological level, lexical level, and syntactic level in terms of style. Therefore, the researcher conducted a stylistic approach in this research. Stylistics is the study of 'distinctive' aspects of language and representation of its purpose and effects (Verdonk, 2002, p. 4). Stylistics could help the researcher figure out the language user's purposes and the text's effects. Besides stylistics, the researcher conducted social distance theory from visual grammar as a supporting theory since the magazine cover contains a picture. Like linguistic structures, visual structures point to a particular interpretation of experience and forms of social interaction (Kress and Leeuwen, 2006, p. 2). With visual grammar, the distance of the subject in the picture can be determined. At a close distance, says Hall (1964), we see the face or head only. At the close personal distance, we take in the head and the shoulders. At the far personal distance, we see the other person from the waist up. At the close social distance, we see the whole figure. At the far social distance, we see the whole figure 'with space around it'. (Kress and Leeuwen, 2006, p. 2).

There are two steps in examining the language and visual features in this research. Firstly, the researcher figured out the language features found in each National Geographic magazine's covers published in June 2020. The researcher later classifies the magazine's cover's language and visual features based on their language levels. Secondly, The researcher figures out the purposes of the language feature found in National Geographic magazine's cover published on June 2020 by analyzing the language and visual features and the picture. In the phonological level, alliteration, assonance, and consonance are analyzed. In the graphological level, the italicization, uppercase, and lowercase are analyzed at the typographical level, the font size and the position of a text are analyzed. In visual grammar, the distance is 
Jurnal DinamikA

Volume 2 No. 2 (2021)

E-ISSN: $2723-1410$

Website: https://jurnal.iainsalatiga.ac.id/index.php/dinamika/index

analyzed. Moreover, the researcher analyses the magazine's covers to reveal the editor's purpose using language and visual features.

\section{Findings and Discussion}

There are four language levels on National Geographic magazine's cover June edition observed and analyzed in the findings and Discussion part. Those language levels are phonological, graphological, typographical, and grammatical levels. The phonological level concerns the pattern related to sound or the rhyme found in the text's language. The first phonological feature is alliteration found in line 4, 5, and 7. The repetition of alliteration is marked by the consonant sound $/ \mathrm{b} /$ in the initial position found in the noun Betty, adjective British, and adverb Bletchley. Those lines can be seen below.

$\begin{array}{ll}\text { Betty Webb, } & \text { line } 4 \\ \text { British } & \text { line } 5 \\ \text { Bletchley } & \text { line } 7\end{array}$

The other alliteration is shown in lines 13 and 14 of the magazine cover. The nouns WORLD and WAR II have the same initial consonant sound, which is /w/. Below is the appearance of the alliteration in lines 13 and 14.

$\begin{array}{lc}\text { WORLD } & \text { line } 13 \\ \text { WAR II } & \text { line } 14\end{array}$

The second phonological feature is consonance. The consonant sound /s/ is repeated at the end of the word. It can be seen in lines 10, 11, 15, 16, 17,18, and 19 with the words LAST, VOICES, years, history's, deadliest, survivors, and stories. Those lines can be seen below.

\section{LAST}

VOICES line 10

line 11 
Jurnal DinamikA

Volume 2 No. 2 (2021)

E-ISSN: $2723-1410$

Website: https://jurnal.iainsalatiga.ac.id/index.php/dinamika/index

$\begin{array}{ll}75 \text { years after the } & \text { line } 15 \\ \text { end of history's } & \text { line } 16 \\ \text { deadliest war, } & \text { line } 17 \\ \text { survivors share } & \text { line } 18 \\ \text { their stories } & \text { line } 19\end{array}$

The analysis of phonological features shows that the repetition of rhymes used is alliteration and consonance. The use of the repetition of rhymes seeks to attract the reader's attention to read the magazine. The repetition of sound /s/in words LAST and VOICES shows the editor's intention to exhibit the magazine's content. The words also represent the aged woman's voices, as seen in the picture. The other repetition is in lines $15,16,17,18$, and 19 , found in words years, history's, deadliest, survivors, and stories. Those words end with consonant sound /s/. With the repetition of the consonant sound /s/ in the magazine cover, the editor wants to make the reader more interested in the content because the repetition of a word can easily be read and remembered.

Graphological level, the editor uses italicization uppercase and lowercase. Italicization can be seen in lines 4, 5, 6, 7, 8, which the texts are Betty Webb, British, Intelligence, and Bletchley Park. Uppercase, as shown in lines 2, 3, 9, 10, 11, 12, 13, 14, which words are NATIONAL, GEOGRAPHIC, THE, LAST, VOICES, OF, WORLD, and WAR II. Last is lowercase, as shown in lines 15, 16, 17, 18, 19, which are 75 years after the, end of history's deadliest war, and survivors share their stories.

Italicization has the purpose of showing the magazine's sub-topic, which tells about Betty Webb, British Intelligence, and Bletchley Park. Italicization may be used for other purposes, such as emphasizing words, but in this magazine, the editor uses it to show the magazine's sub-issue.

Uppercase has the purpose of conveying and emphasizing the important message to the reader. The editor uses uppercase in two noun phrases that are spread in several lines, such as NATIONAL GEOGRAPHIC and THE LAST VOICE OF WORLD WAR II. The noun phrase NATIONAL GEOGRAPHIC is uppercased 


\section{Jurnal DinamikA}

Volume 2 No. 2 (2021)

E-ISSN: 2723-1410

Website: https://jurnal.iainsalatiga.ac.id/index.php/dinamika/index

because it is the brand, trademark, or the name of the magazine itself, in which it has to be emphasized as the editor does. Then, the noun phrase THE LAST VOICE OF WORLD WAR II is uppercased because it is the headline of the magazine. The magazine's headline is significant to be emphasized because the primary information contained in the magazine is represented in the headline. Therefore, the editor's purposes of uppercasing the magazine's name and the headline are to convey and emphasize the message and information contained in the magazine.

The lowercase has the purpose of describing the capitalized text. As found in lines $15,16,17,18$, and 19 , the editor wants to show the less dominant text supporting and giving further information about the headlines.

In the typography level, there are several features analyzed; they are font size and the position of the text. Here, the researcher classifies and analyses the font size based on the largest to the smallest text. There are five different sizes of the font used by the editor of the magazine. Those can be seen in the tables below.

Table 1. The largest font size text

\begin{tabular}{|r|c|c|}
\hline 1. & LAST & Line 10 \\
\hline 2. & VOICES & Line 11 \\
\hline 3. & WORLD & Line 13 \\
\hline 4. & WAR II & Line 14 \\
\hline
\end{tabular}

The largest text's font size relies on the word LAST, VOICES, WORLD, and WAR II. The large text on the magazine cover, website, book cover, etcetera has an essential role in highlighting its meaning. It also has an essential role to draw the reader's attention; for instance, when someone reads a book, they would see the most extensive writing first. It would happen because the massive thing must be more comfortable to see rather than the small thing. Therefore, the editor or the author of some writings would use a large font size to highlight the important message. The 
Jurnal DinamikA

Volume 2 No. 2 (2021)

E-ISSN: 2723-1410

Website: https://jurnal.iainsalatiga.ac.id/index.php/dinamika/index

editor of this magazine uses the largest font size on those above words to highlight the headline, which contains the magazine's central issue, which is essential to be delivered to the reader.

Table 2. The second-largest text's font size

\begin{tabular}{|r|c|c|}
\hline 1. & NATIONAL & line 2 \\
\hline 2. & GEOGRAPHIC & line 3 \\
\hline
\end{tabular}

The second-largest text's font size relies on the words NATIONAL and GEOGRAPHIC. The same with the analysis of the most extensive text's font size, NATIONAL and GEOGRAPHIC are also written in large size. However, these words are not more prominent than the words in the first table. It can be seen that there is a contrast that the editor wants to convey. National Geographic is a brand of the magazine that is also well-known. Therefore, it is not necessary to highlight them. By making them smaller than the words in the first table, the headline, the editor emphasizes that these words are less prominent.

Table 3. The third-largest text's font size

\begin{tabular}{|r|c|c|}
\hline 1. & THE & Line 9 \\
\hline 2. & OF & Line 12 \\
\hline
\end{tabular}

The third-largest text's font size relies on the words THE and OF. These words perform as a determiner and a preposition of the headline in the table number 3 . Since the word THE performs as a determiner and the word OF performs as a preposition, they are only used to complete the phrase's structure. They do not give any meaning to the phrase, which makes them not too significant. Therefore, the editor makes them smaller than the words in table 1 , even though they are in the same phrase. 
Jurnal DinamikA

Volume 2 No. 2 (2021)

E-ISSN: $2723-1410$

Website: https://jurnal.iainsalatiga.ac.id/index.php/dinamika/index

Table 4. The fourth-largest font size text

\begin{tabular}{|r|c|c|}
\hline 1. & 75 years after the & Line 15 \\
\hline 2. & end of history's & Line 16 \\
\hline 3. & deadliest war, & Line 17 \\
\hline 4. & survivors share & Line 18 \\
\hline 5. & their stories. & Line 19 \\
\hline
\end{tabular}

The fourth-largest text's font size relies on the fragments of phrase which are spread in six lines. They are 75 years after the, end of history's, deadliest war, survivors share, and their stories. These fragments of phrases are written in small font size. The phrase has the purpose of describing the headlines, which is the magazine's edition's central issue. Therefore, the editor uses a small font size to make it get less attention so that the reader focus on the headline first.

Table 5. The fifth-largest text's font size

\begin{tabular}{|r|c|c|}
\hline 1. & Betty Webb, & Line 4 \\
\hline 2. & British & Line 5 \\
\hline 3. & Intelligence, & Line 6 \\
\hline 4. & Bletchley & Line 7 \\
\hline 5. & Park & Line 8 \\
\hline
\end{tabular}

The fifth-largest text's font size relies on the fragments of phrase which are spread in five lines. They are Betty Webb, British, Intelligence, and Bletchley Park. This phrase gives the reader information about the sub-issues contained in the magazine. However, the central issue and its description are more essentials than sub-issues. Therefore, that is the reason why the editor uses the small font size in this phrase.

Table 6. The smallest text's font size 
Jurnal DinamikA

Volume 2 No. 2 (2021)

E-ISSN: $2723-1410$

Website: https://jurnal.iainsalatiga.ac.id/index.php/dinamika/index

\begin{tabular}{|r|c|c|}
\hline 6. & 06.2020 & Line 1 \\
\hline
\end{tabular}

The smallest text's font size relies on the date of the edition, which is 06.2020. Here, the editor uses the smallest font size compared to the others to convey to the readers that the most critical information on the cover relies on the headline or the central issue, not the edition's date.

The position of the text is essential in typography. Therefore, the researcher analyses the position of the text in the magazine. The first table and third table contain the phrase of the central issue of the magazine. It is located on the middleright side of the magazine beside the picture of the aged woman. The editor intends to make the reader directly read the headline right after seeing the picture. So, the reader can relate the relation between the picture and the headline. The second table contains the phrase, which is the name of the magazine. The editor locates it on the magazine's top to show the authenticity of the Natgeo magazine's cover, which always puts the magazine's name on the top position. The fourth table text is located on the bottom middle-right of the magazine, below the headline. The editor puts it there to tell the reader that the phrase is describing the headline. The phrase of the fifth table is located on the top middle-left of the magazine. The editor puts the phrase there to inform the reader that there are minor issues served in the magazine. The text in the sixth table is located in the very top middle of the magazine. The editor puts it there to show the edition of the magazine to the reader.

In supporting the analysis of language levels, the researcher employes interactive meaning of visual grammar. According to Kress and Leeuwen (2006), interactive meaning is defined as a description of the relationship of image marker, image representation, and readers. The features, including in the interactive meaning, are contact, attitude, distance, and modality. There are many features of interactive meaning, but this research only focuses on distance.

Hall, as cited by Kress and Leeuwen (2006), describes how social relations are determined by different fields of vision in images. To make it more straightforward, 


\section{Jurnal DinamikA}

Volume 2 No. 2 (2021)

E-ISSN: 2723-1410

Website: https://jurnal.iainsalatiga.ac.id/index.php/dinamika/index

the researcher includes the summary of social distance that can be seen in the table below.

Table 1. Distance, the field of vision, and relations

\begin{tabular}{|c|c|c|}
\hline Distance & Field of vision & $\begin{array}{c}\text { Relationship between } \\
\text { represented } \\
\text { participant and } \\
\text { viewers }\end{array}$ \\
\hline Intimate & $\begin{array}{c}\text { Only the face of the } \\
\text { head is visible }\end{array}$ & Intimate \\
\hline $\begin{array}{c}\text { Close personal } \\
\text { distance }\end{array}$ & $\begin{array}{c}\text { The head and the } \\
\text { shoulders are visible }\end{array}$ & Intimate \\
\hline Far personal & $\begin{array}{c}\text { The area from the head } \\
\text { to the waist is visible }\end{array}$ & Personal \\
\hline distance & $\begin{array}{c}\text { The whole figure is } \\
\text { visible }\end{array}$ & Impersonal \\
\hline distance & $\begin{array}{c}\text { The whole figure and } \\
\text { the space around it is } \\
\text { var social }\end{array}$ & Formal and \\
distance & impersonal \\
\hline Public distance & $\begin{array}{c}\text { The torsos of at least } \\
\text { four or five people are } \\
\text { visible }\end{array}$ & Strangers \\
\hline
\end{tabular}

Each National Geographic Magazine uses pictures in its front cover. The June edition includes a picture of an aged woman sitting on the chair staring straight to the camera. In analyzing distance, the represented participant's position, the aged woman on the frame, is essential. As described in the above table, the field of vision determines the distance and the relationship between the presented participant and viewers or readers. The aged woman's picture has headroom and the space on the left and right side on the magazine's cover. However, the waist of the aged woman collides 


\section{Jurnal DinamikA}

Volume 2 No. 2 (2021)

E-ISSN: 2723-1410

Website: https://jurnal.iainsalatiga.ac.id/index.php/dinamika/index

with the frame of the magazine cover. Because the head to the aged woman's waist is visible, it can be determined that the distance is far from a personal distance. The relationship between the represented participant and the readers is personal.

The editor has the purpose of using the aged woman's picture at the far personal distance on the magazine cover. The presented figure on the magazine cover has the purpose of strengthening the issue of the magazine. It is also depicting the issue discussed inside the magazine. By presenting the aged woman's picture at a far personal distance, the editor creates personal proximity to the reader, which implies that the aged woman wants to voice her idea or the testimony of living in the world war era.

\section{Conclusion}

The stylistic analysis of language features from different language levels is proven in revealing the editor's purposes of using specific language features. In this research, the researcher analyses three language levels: phonology, graphology, and typography. In the level of phonology, the features are assonance, alliteration, and consonance.

In the level of graphology, the features are italicization, uppercase, and lowercase. In the level of typography, the features are font size and the position of the text. Besides language levels, this research employs visual grammar to support the stylistics in analyzing the picture. In visual grammar, the analyzed feature is distance. Those features are analyzed to reveal the editor's purposes of using language and visual features.

The purposes of the editor using certain features are revealed. At the phonological level, assonance, alliteration, and consonant are easy to be remembered and understood. As found in the analysis, the repetition of consonant sound /s/ in the phrases THE LAST VOICES OF WORLD WAR II and 75 years after the end of history's deadliest war, survivors share their stories have a purpose of making them easy to be remembered and understood by the readers. In the graphological level, the use of 


\section{Jurnal DinamikA}

Volume 2 No. 2 (2021)

E-ISSN: 2723-1410

Website: https://jurnal.iainsalatiga.ac.id/index.php/dinamika/index

italicization, uppercase, and lower case have purposes to emphasized and deemphasized the text found in the cover based on the most essential. For instance, the editor uses lowercase in the phrase 75 years after the end of history's deadliest war, survivors share their stories because it is not more essential than the headlines. In the level of typography, the features are font size and the position of the text. For example, the font size of the phrase THE LAST VOICES OF WORLD WAR II is the largest compared to the others. It has a purpose to highlight the phrase because of the headline. The last feature comes from visual grammar, which is distance. The editor has the purpose of using the aged woman's picture at the far personal distance on the magazine cover to create personal proximity to the reader. To conclude, the stylistics is proven in revealing the editor's purposes of using language and visual feature in the magazine cover. This research analyzes language features and a visual feature in analyzing the magazine cover. The further researchers can elaborate and develop more by adding more features of visual grammar along with this research.

\section{References}

Baron, Naomi S. (2013). Redefining Reading: The Impact of Digital Communication Media. Modern Language Association, Vol. 128, pp.193-200.

Crystal, D (2008). A Dictionary of Linguistics and Phonetics. Oxford: Blackwell publishing.

Dominick, Joseph R. (1996). The Dynamics of Mass Communication. New York. The Mac Graw Hill Compan

Famila, A. C. (2016). A Stylistic Analysis on The View Column in Vogue Magazine, April 2015, June 2015, and December 2015 Editions (Undergraduate Thesis). Universitas Sanata Dharma, Yogyakarta.

Kress \& Leeuwen (2006). Reading Images: The Grammar of Visual Design. The second edition. Abingdon, Oxon: Routledge, Taylor \& Francis Group. 


\section{Jurnal DinamikA}

Volume 2 No. 2 (2021)

E-ISSN: $2723-1410$

Website: https://jurnal.iainsalatiga.ac.id/index.php/dinamika/index

McLoughlin, L. (2002). The Language of Magazine. London: Routledge.

Susanto, C. M. C. (2019) The Use of Pre-Modifiers and Post-Modifiers of Noun Phrases in Revlon Lipstick Advertisements in Female Online Magazines Editions (Undergraduate Thesis). Universitas Sanata Dharma, Yogyakarta.

Verdonk, P. (2002). Stylistics. Oxford: Oxford University Press.

\section{Appendices}

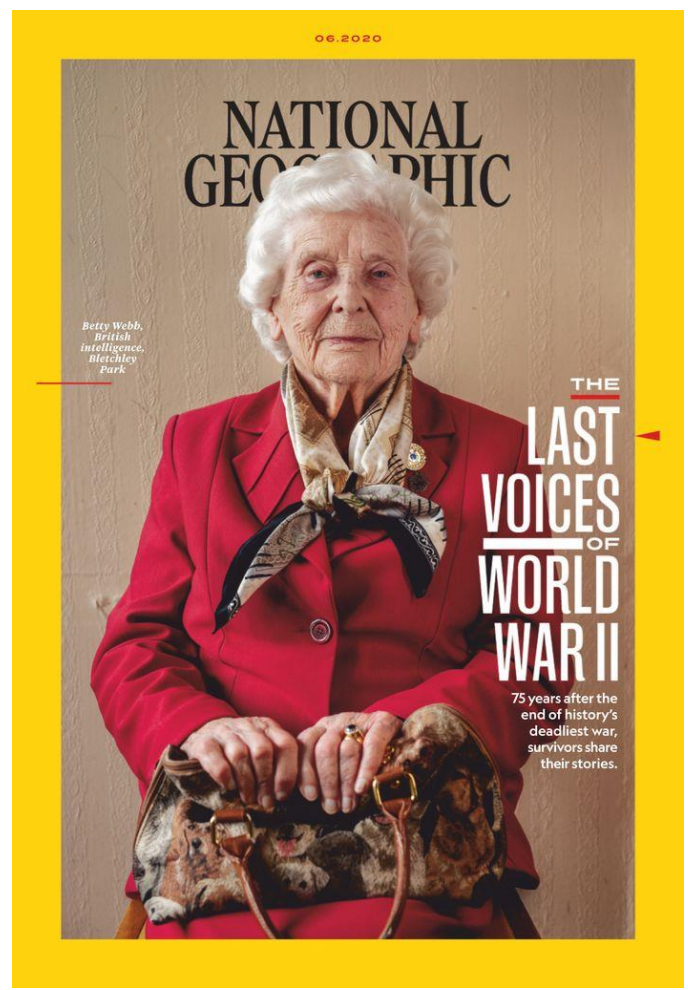

